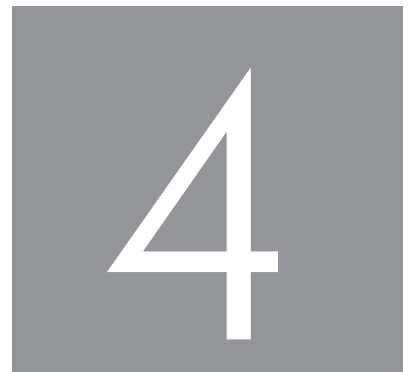

\title{
UNIVERSITIES AND PUBLIC GOODS
}

IN DEFENCE OF DEMOCRATIC DELIBERATION, COMPASSIONATE IMAGINING AND COSMOPOLITAN JUSTICE

\author{
Yusef Waghid
}

\section{ABSTRACT}

One of the most significant contributions to the advancement of modern higher education is found in the work of Frank and Meyer (2007:290) who argue that the public mission of the contemporary university is to assist in addressing great social problems such as improving business organisation and capital investment, protecting the natural environment, preserving human rights and cultural diversity, resolving crises of governance and promoting democracy - all aspects that constitute what can be referred to as the public goods of higher education. In order to foreground the public mission of the modern (African) university more clearly, I offer an account of higher education as a public good which ought to build on conceptions of democratic deliberation, compassionate imagining and cosmopolitan justice.

\section{INTRODUCTION}

Any philosophical contribution to the end goals of university education cannot ignore the invaluable epistemological contributions research for 'its own sake' has made to erudite scholarship in most modern societies. I do not wish to deny that pursuing research for 'its own sake' or research that is not supposed to produce some kind of instrumental end result such as socio-economic development is of no use to increase the vast riches of scholarship. My use of the term research for 'its own sake' is meant to convey that knowledge is produced for understanding, but that such knowledge does not necessarily have in mind any concrete benefits for society. My point is that the production of knowledge for 'its own sake' has always contributed to the production of more knowledge and was not necessarily intended for developmental purposes. 


\section{PART TWO • NORMATIVE AND EPISTEMOLOGICAL ISSUES}

Examples of such knowledge can be related to questions such as: Do numbers exist outside of our minds? Do human beings have dreams outside of their real existence? Is the universe continuously expanding? Should virtue be taught? Often these questions, which were intrinsically pursued for 'their own sake', had other consequences which might have resulted in knowledge of benefit to societies. Hence, I am not suggesting that universities should not encourage the pursuit of knowledge for 'its own sake', because I do not conceive of knowledge for 'its own sake' as being unable to make any difference to human lives. The key argument of this contribution is not against the production of knowledge for 'its own sake', but is rather a defence of knowledge for the purpose of achieving substantive socio-economic development, especially on the African continent. For me a public university in the modern age has to make the pursuit of knowledge for the good of society one of its most important purposes, if not the most significant one. In line with this approach I shall make an argument for the cultivation of three public goods that ought to constitute university education on the African continent: deliberative democracy, compassionate imagining and cosmopolitan justice.

My defence of knowledge for the purposes of socio-economic development builds on the seminal work of Frank and Meyer (2007:267-268), who argue that any society is always distinguished by the degree to which that society is organised around the university's abstracted and universalised understandings of the world and its degreecertified graduates. For them, it is the university which provides the "differentiated training and research programs functionally required by complex societies or their power structures, and may even play a role in producing desired social development" (Frank and Meyer 2007:268). What this implies is that the university is called upon to help alleviate great social problems - improving business organisation and capital investment, protecting the natural environment, preserving human rights and cultural diversity, resolving crises of governance and promoting democracy in every country around the world. Simultaneously, the university is accountable for the way it addresses the immediate problems at hand - training local business leaders, preserving local cultures, improving local child-rearing practices, protecting local species, and so on (Frank and Meyer 2007:290). Simply put, university education ought to attend to and be accountable for societal development, albeit at a scientific, technological, political, cultural or economic level. As I have argued elsewhere, the university should indeed perform a public role by creating opportunities for its students and academics to take responsibility for their own ideas, to take intellectual risks, to develop a deep sense 
of respect for others, and learn how to think and engage critically with others in a democratic society (Waghid 2008:23)

Before I offer some indications of how and why this public role of the university can most appropriately be enhanced through democratic deliberation, compassionate imagining and cosmopolitan justice - those intrinsic goods which can engender university education as a public good - I first need to give an overview of the status of higher education on the African continent.

\section{CHALLENGES FACING HIGHER EDUCATION ON THE AFRICAN CONTINENT}

Undoubtedly, universities face many challenges on the African continent. AssiéLumumba (2006:71) poignantly argues that from the late 1970s to the 1990s higher education, especially in universities in Africa, was characterised by great instability as indicated by numerous confrontations between students, faculties, administrations and governments. This instability has been further compounded by economic failures, stagnation and regression, which adversely affect the advancement of higher education on the continent (Assié-Lumumba 2006:75). Some of the main reasons for the ill-preparedness of African universities to meet societal needs are their alienation from the broader society and business community, and the inefficiency of university administration, organisation and management (Assié-Lumumba 2006:78).

Teferra and Altbach (2003:4) argue that the influence of colonialism on African higher education contributed towards restricting student access, undermining the teaching of students in indigenous languages, limiting academic freedom and constraining the Africanisation of the curriculum. Colonial authorities were only interested in training limited numbers of African nationals to assist them in the administration of their colonies. Although France used to send members of the colonies to France for higher education training, Zaire (now the Democratic Republic of Congo) did not have a single national as an engineer, lawyer or doctor at the time of independence. Likewise, the higher education system in the colonies was also characterised by use of the adopted language of instruction, which was the language of the coloniser. This was coupled with limited forms of freedom within the academy. Teferra and Altbach (2003:4) also indicate that at independence the curricula of universities were dramatically restructured. The discipline of law tended to be favoured in the past more, because it aided the colonial administrator in his work, but other disciplines such as science were not much encouraged. Although the curriculum of African universities today includes almost all subject areas, one would expect that in a university the ties 


\section{PART TWO • NORMATIVE AND EPISTEMOLOGICAL ISSUES}

to the former colonial countries would remain strong, and in no case has a country in Africa dramatically changed its language of instruction.

War and conflict have also affected post-secondary education in some African countries. For instance, war and national strife virtually brought the higher education system to a standstill in countries such as Somalia, Angola and the Democratic Republic of Congo (Teferra and Altbach 2003:3). Also, as aptly put by Teferra and Altbach: "Inadequate financial resources compounded with unprecedented demand for access, the legacy of colonialism, long-standing economic and social crises in many countries and the challenges of HIV/AIDS in many parts of the continent present the higher education sector with a bigger challenge" (Teferra and Altbach 2003:3). According to these authors, the declining economies of African states have made it difficult for universities to train staff who can manage their systems. This problem is compounded by the high prevalence of HIV/AIDS on the continent, which has affected Africa's workforce in general.

The higher education landscape on the African continent has largely been sustained by funding from national governments. At the inception of these institutions national governments saw it as their mandate to provide for universities and they therefore completely subsidised this sector. But with the growing demand for public money in other sectors of life, national governments have begun to encourage universities to diversify the means of providing for their finances. South African universities rely less on state funding compared to other universities on the continent. There seems to be a general expectation across the continent that when government funds higher education, then the goals and aims of government should be promoted through the higher education system. For instance, Singh (2001:8) proposes that we should understand a university in Africa from a functional perspective in terms of the common good that higher education is meant to promote. What is clear in Singh's perspective is the idea that there is no university that exists for itself; neither is there such a thing as the pursuit of knowledge for its own sake only. This is the case, because examining the core functions of the university critically reveals that the functions of teaching, research and community engagement are interrelated, and that one function on its own cannot fully represent the core functions of the university. This thinking is very much at the heart of the view that at the end of the day any university is supposed to respond to, and enhance, the public good. I now turn to a discussion of this issue. 


\section{UNIVERSITY EDUCATION AND DEMOCRATIC DELIBERATION}

Against the backdrop of the afore-mentioned challenges faced by universities in Africa, I wish to explore how and why democratic deliberation can potentially contribute towards a defensible university education, which in turn can enhance socioeconomic development. Now, in the light of the fact that unproductive confrontations between students and university staff are cited as one of the main contributory factors towards eventual economic, political and social instability in African societies, I want to make a case for cultivating the practice of deliberative democracy in universities. Of course, practising deliberative democracy does not mean that people should be less confrontational and assertive. Instead, democratic deliberation has as its goal that university staff should not merely listen to the narratives of students, but actually encourage a spirit of living together in diversity - that is, through democratic deliberation university staff and students together establish opportunities which take into account people's linguistic, cultural, ethnic and religious commonalities and diversity. The idea of finding a deliberative space for the sharing of different people's commonalities is based on the understanding that people need to learn to live with the otherness of others whose ways of being may be deeply threatening to our own. And, by creating a deliberative space (Benhabib 2002:127) where people can enact what they have in common and at the same time make public their competing narratives and significations, people might have a real opportunity to co-exist. In this way they would not only establish a community of conversation and interdependence (that is, they share commonalities), but also one of disagreement (that is, they do not share commonalities) without disrespecting others' life-worlds (Benhabib 2002:35,41). Put differently, when university staff and students are engaged in deliberative engagement underpinned by interdependence and disagreement, they engage in democratic action with a collective identity - they share commonalities. And educating students to become deliberative democrats involves creating civil spaces where they can learn to share commonalities and to respect the differences of others.

My potential critic might legitimately ask whether deliberative democracy is necessarily good for Africa considering the diversity of views about the concept. In the first instance, deliberative democracy unfolds when educators and students engage dialogically; all have the same chances to initiate speech acts, to question, to interrogate and to open debate; all have the right to question the assigned topics of conversation; and all have the right to initiate reflexive arguments about the very rules of the discourse procedure and the way in which they are applied or carried out (Benhabib 1996:70). Such dialogical action, which involves interrelated actions such as debate, questioning, 
discussion and argumentation, constitutes public deliberation. Now considering that the word ubuntu (human interdependence through deliberative inquiry) is found in almost all African languages, although not necessarily under the same name, the argument can be made that the notion must have had currency amongst Africa's people in the past. For example, in Kenyan languages such as Kikuyu and Kimeru ubuntu is referred to as umundu and umuntu; in kiSukuma and kiHaya of Tanzania ubuntu is referred to as bumuntu; in shiTsonga and shiTswa of Mozambique ubuntu is referred to as vumuntu; in Bobangi spoken in the Democratic Republic of the Congo ubuntu is referred to as bomoto; and in kiKongo of Angola ubuntu is referred to as gimuntu (Kamwangamalu 1996:26). And, the fact that ubuntu like deliberative democracy (as I have articulated elsewhere) is a form of communal engagement which allows space for criticality, non-domination and ensuring that human relationships flourish, the practice of deliberative democracy can be considered as specifically of relevance to African societies because of its history of colonisation, racial oppression and segregation, and economic, political and social instabilities, insecurities and complexities - all those societal ills which potentially stand a better chance to be eradicated through democratic deliberation (Waghid 2009).

Callan (1997:215) favours a conception of democratic deliberation characterised by the distress and belligerence (that is, a rough process of struggle) of confrontation that will naturally give way to conciliation as moral truth is pieced together from the fragmentary insights of conflicting viewpoints. For him, the idea of democratic deliberation is not an attempt "to achieve dialogical victory over our adversaries but rather the attempt to find and enact terms of political coexistence that we and they can reasonably endorse as morally acceptable" (Callan 1997:215). Through democratic deliberation, participants disturb doubts about the correctness of their moral beliefs or about the importance of the differences between what they and others believe (a matter of arousing distress) accompanied by a rough process of struggle and ethical confrontation - that is, belligerence (Callan 1997:211). If this happens, belligerence and distress give way eventually to moments of ethical conciliation, when the truth and error in rival positions have been made clear and a fitting synthesis of factional viewpoints is achieved (Callan 1997:212). This is an idea of democratic deliberation, with which I agree, where no one has the right to silence dissent and where participants can speak their minds. In the words of Callan (1997:201-202), "real moral dialogue (as constitutive of democratic action), as opposed to carefully policed conversations about the meaning of some moral orthodoxy, cannot occur without the risk of offence, an offence-free school [university] would oblige us to eschew dialogue". It seems that 
some university staff listening to students' narratives become culpable of steering the conversation in such a way that the substantiveness of articulated views no longer has priority. Rather, these teachers seem to focus on who the students are and not also what they substantively have to say. I sometimes hear students' claims that it is difficult to write a section of a thesis, because they were not taught argumentation in their undergraduate studies. Of course, this might be true. But then, to have reached the stage of thesis writing, one should at least know what it means to present a lucid, substantiated and coherent argument. For this reason it would not be inappropriate to confront and even offend students. Simply put, tell students that their writing is not good enough and that they could do something about improving it.

The upshot of such a view of democratic deliberation is that university staff and students do not have to move towards non-confrontational relationships. Instead they need to confront one another with the intention of moving towards more amicable relations. Democratic deliberation does not mean that we have to police our engagements so as to avoid belligerent confrontations, because the latter situation can allow people to speak their minds, talk back and offer alternative points of view after having considered critically what others have to say. Student-staff relations at universities often lead to violent threats, causing much instability that can be counter-productive for societal development simply because people do not afford themselves the space to engage in democratic deliberation.

\section{UNIVERSITY EDUCATION AND COMPASSIONATE IMAGINING}

War and conflict (the latter often of a violent nature) seems to be endemic to many countries on the African continent. Elsewhere I have argued that religious extremism and political autocracy are major factors which perpetuate violence in African societies (Waghid 2007:192). In this chapter I want to extend my argument and attribute violent conflict to a lack of practising compassionate imagining, which I hold can be taught at universities. And if this can be done (hopefully so), African societies might have a real chance to experience peaceful human co-existence and interdependence - precisely those aspects which can enhance societal development. Martha Nussbaum (2001) raises the question of what a positive contribution emotions such as compassionate imagining can make in shaping relations amongst university staff and students. Her main argument in defence of compassionate imagining is that the latter ought to be the practice that should be most frequently cultivated when people embark upon democratic action in public life (Nussbaum 2001:299). It is her view that democratic deliberation ought to be occasioned by the impulse to treat others justly and humanely 


\section{PART TWO • NORMATIVE AND EPISTEMOLOGICAL ISSUES}

- with compassion. Certainly in African universities - where a diversity of students from advantaged and disadvantaged backgrounds are beginning to deliberate about matters of public concern such as crime, victimisation, homelessness, job discrimination, unemployment, domestic violence and abuse of women, poverty and lack of food, political alienation, alcoholism and drug abuse, and the absence of good prospects certain practical judgements have to be made by students about these variants of their public and personal lives. Invariably, judgements to be made will be based on students' perceptions of the distressing plight of others, undeserved misfortune, suffering, injustice, disability and disease. It is in this regard that compassionate imagining becomes a necessary condition to deliberate about such matters. Compassionate imagining not only prompts an awareness in people of the misfortune or suffering of others, but also pushes the boundaries of the self outward by focusing on others' suffering which might be caused by no fault of their own (Nussbaum 2001:299).

Nussbaum's understanding of compassionate imagining as painful emotional judgement embodies at least two cognitive requirements: firstly, a belief or appraisal that the suffering of others is serious and not trivial, and that persons do not deserve the suffering; and secondly, the belief that the possibilities of the person who experiences the emotion are similar to those of the sufferer. I shall now discuss these two requirements of compassionate imagining in relation to the way that students and university staff ought to deliberate rationally (which includes being good listeners), yet also at the same time cultivating in them the concern to be just and humane towards others - to be compassionate.

Insofar as one can become serious about the suffering of others, one believes them to be without blame for the kind of undeserved injustice they might have suffered, and one recognises that the person's plight needs to be alleviated. Many students, who are perhaps blameless for their inability to pay university fees because their parents did not enjoy economic prosperity after decades of racial discrimination, require the compassion of others. In such circumstances, deliberation at universities should rather take the form of ascertaining what could be done to ensure that students who do not have the finances to study remain part of the university community, rather than finding ways to penalise or at times humiliate them. So compassionate imagining requires an acknowledgement of blamelessness on the part of students who are unable to pay university fees, as well as onlookers who can make judgements about the need to expedite the creation of conditions under which the students in question can flourish. Similarly, a university staff member can have compassion for students from an impoverished educational background, which is not necessarily their responsibility 
(the parents might not have been able to afford to send their children to more affluent and organised schools or to pay for the services of extramural tuition, as is the case in South Africa). Such a university staff member recognises the need to find creative ways to assist disadvantaged students to come to grips with difficult concepts in their studies and at the same time acknowledges that the unjust education system to which these students might have been exposed is no fault of their own. One could argue that all students should be treated equally and that no student should receive preferential treatment in terms of additional pedagogical support. But then this would be to ignore the undeserved unequal education many students, certainly in South Africa, have been - or might still be - subjected to.

Also, compassionate imagining is best cultivated if one acknowledges some sort of community between oneself and the other, understanding what it might mean for one to encounter possibilities and vulnerabilities similar to those of the sufferer: "[One] will learn compassion best if [one] begins by focusing on their sufferings" (Nussbaum 2001:317). Again, "in order for compassion to be present, the person must consider the suffering of another as a significant part of his or her own scheme of goals and ends. She must take that person's ill as affecting her own flourishing. In effect, she must make herself vulnerable in the person of another" (Nussbaum 2001:319). What this recognition of one's own related vulnerability means is that students, who might have a clear understanding of, say, concepts in a literature classroom and become impatient with their peers for not grasping such concepts, should imagine what it would mean for them to encounter difficulty with concepts. Likewise, university academics teaching literature studies should become more aware of what it means for students to encounter epistemological difficulty. In the words of Nussbaum (2001:319), "the recognition of one's own related vulnerability is, then, an important and frequently an indispensable epistemological requirement for compassion in human beings".

In essence, compassionate imagining brings to the fore the intellectual emotions of people in ethical deliberation. It is simply not sufficient to educate by just focusing on democratic deliberation without also cultivating compassionate imagining. Democratic deliberation prompts students and university staff to question meanings, imagine alternative possibilities, modify practical judgements, and foster respect and critical engagement. Yet, it seldom brings into play those emotions of people that are necessary to make it worthwhile to continue the deliberative interaction. If one is going to ignore the pedagogical vulnerabilities of the weak, very little will be done in the direction of meaningful education. So we also need compassionate students and university staff. 


\section{PART TWO • NORMATIVE AND EPISTEMOLOGICAL ISSUES}

If people are taught compassionate imagining at universities, our institutions on the African continent would inevitably contribute towards producing a workforce capable of recognising the vulnerabilities of others. And this is what African societies require if we hope to eradicate the kinds of violent confrontations that are currently witnessed on the continent. This brings me to a discussion of university education in relation to cosmopolitan justice.

\section{UNIVERSITY EDUCATION AND COSMOPOLITAN JUSTICE}

I begin this section with the following questions: Should universities always promote the goals of government's higher education policies? What if the state expects of its universities to prepare staff who can contribute towards national policies and which can result in alienation of the other? For instance, should universities give preference in their appointments policy to the country's own citizens, although immigrants might be more suitably qualified to perform the job? On the one hand, the state provides the funding for higher education and rightfully so, and therefore expects cooperation from universities in implementing its policies and goals. On the other hand, universities are made up of academics who require the freedom to exercise their minds, which might not always connect with doing exactly what the state requires. For instance, if governments require the universities which they fund to restructure their academic offerings so as to ensure that students are produced who can serve the labour market economy, then universities should consider producing such marked-related academic offerings. But this does not mean that universities should forfeit their freedom to challenge and even undermine through critical inquiry what potential harm a marketdriven academic offering can do to society. Similarly, universities should not encourage a culture whereby those considered as other (for instance, immigrants) should not be afforded equal opportunities. Too much strife which leads to exclusion of the other is already alarmingly evident on the African continent, which does not augur well for peaceful human co-existence. This is where I would encourage universities to embark on the cultivation (through teaching and learning) of cosmopolitan justice.

Considering that cosmopolitan justice involves the right to temporary residence on the part of the "stranger who comes to our land" (Benhabib 2006:22), it follows that universities in Africa cannot deny access to students of immigrant communities. In most cases they are not refused. However, some students are excluded in subtle ways, considering that the language of instruction, for instance, is not in the mother tongue of these immigrant students. What cosmopolitan justice demands is for immigrant students to be taught initially in their mother tongue before they are assimilated into 
the broader public university life. Or, alternatively, they should simultaneously learn the language of instruction and be supported in doing so. The point I am making is that one should not take for granted that people with immigrant status would fit naturally into the public structures of their adopted countries or countries of temporary residence. They have to be initiated gradually into public life on the basis of a sense of obligation on the part of democratic states. Failing to do so by, for example, denying immigrant students gradual access into public universities and thus depriving them of the opportunity to develop and exercise their capacities would amount to treating others unjustly.

Also, 'the right to have rights' prohibits states from denying individuals citizenship rights and state protection against murder, extermination, enslavement, deportation and other inhumane acts such as persecution (whether political, cultural or religious) (Benhabib 2006:25). If Somali immigrant students wish to wear their headscarves in public universities, following 'the right to have rights' notion, these students cannot be discriminated against if they wish to do so. Asking these students to remove their scarves, which they might consider as important to their religious and cultural identity, would be a matter of treating them unjustly on the grounds that their right to be different would be undermined. In essence, cosmopolitan justice and its concomitant agenda of hospitality which ought to be afforded to other human beings (especially from immigrant communities) in many ways complement the duties and responsibilities associated with the activities of democratic citizens. Unless African countries and their peoples recognise the rights of others to be treated with dignity and respect, without suppressing their rights, the achievement of justice will remain remote from the minds and hearts of people.

What follows from the above is that universities cannot be exonerated from cultivating in their students and staff the notion of cosmopolitan justice. Too much anger, antagonism, hatred and violence seem to permeate African societies. And although one might argue that universities should focus on advancing the sciences, we cannot ignore our African realities. In any case, for universities to function as legitimate institutions in Africa, building and extending the canons of critical inquiry, advancing the disciplines and preventing and subverting dogmatism, we cannot afford to turn a blind eye to teaching and learning cosmopolitan justice. To begin with, we would learn what it means to treat another person with respect and dignity and in this way pave the way for more hospitable societal relations, whether at work, university or in our families. If such hospitable relations do not exist, the chances of universities advancing 
the rational sciences might become a remote impossibility - a situation that Africa could not even begin to tolerate.

\section{CONCLUSION}

In this chapter I have made a case for higher education, more specifically universities, to engender education for democratic deliberation, compassionate imagining and cosmopolitan justice. Only if universities are prepared to take seriously the cultivation of these virtues can we begin to revive the university systems on the African continent. Invariably, teaching these virtues creates the possibility for universities to make a constructive contribution towards advancing socio-economic development. And in this way they begin to take more seriously their public role.

However, would the pursuit of socio-economic development necessarily undermine the economic rationalist agenda the university in Africa ought to embark upon? One cannot dispute the economic importance of higher education. But to see the university as performing only this economic function is a misplaced and indefensible idea. Today, higher education has become a commodity in the global education market aiming to serve the knowledge society through "the production, transmission and dissemination of high-quality knowledge" (Simons 2006:33). In this chapter I have argued that the university in Africa has a role to play in cultivating democratic deliberation, compassionate imagining and cosmopolitan justice and, that this can most appropriately be done by reconsidering its public role in relation to socioeconomic development.

Finally, what are some the implications of this contribution to future research possibilities in higher education in and about Africa? This contribution attempts to foreground the public mission of African universities in relation to the concepts deliberative democracy, compassionate imagining and cosmopolitan justice. Yet, some of the most salient challenges currently faced by higher education institutions on the African continent, more specifically universities in relation to a restricted access to universities, persistent societal conflicts, inadequate financial resources and economic dependency, the commodification of knowledge, a curb on academic freedom and institutional autonomy, and a lack of quality education and qualified staff, remain unexplored in relation to deliberative democracy, compassionate imagining and cosmopolitan justice. This contribution potentially opens the possibility to pursue such explorations. Likewise, an issue that has not been addressed in this chapter is an argument as to why higher education in Africa ought to become more concerned with an extended notion 
of Africanisation - more specifically the practice of integrating ubuntu and deliberative democracy which can possibly advance the achievement of justice on the African continent. Then, I also think that overextending deliberative democracy to agonism would not necessarily be feasible for higher education institutions in Africa. This is also an issue which future researchers might wish to embark upon.

\section{REFERENCES}

Assié-Lumumba N. 2006. Higher Education in Africa: Crises, Reforms and Transformation. Dakar: Council for the Development of Social Science Research in Africa.

Benhabib S. 1996. Toward a deliberative model of democratic legitimacy. In: S Benhabib (ed). Democracy and Difference: Contesting the Boundaries of the Political. Princeton: Princeton University Press. 67-94.

Benhabib S. 2002. The Claims of Culture: Equality and Diversity in the Global Era. Princeton: Princeton University Press.

Benhabib S. 2006. The philosophical foundations of cosmopolitan norms. In: R Post (ed). Another Cosmopolitanism. Oxford: Oxford University Press. 13-44.

Callan E. 1997. Creating Citizens: Political Education and Liberal Democracy. Oxford: Oxford University Press.

Frank DJ \& Meyer JW. 2007. University expansion and the knowledge society. Theory and Society, 36(1):287-311.

Kamwangamalu NM. 1996. Ubuntu in South Africa: A sociological perspective to a PanAfrican concept. Critical Arts, 13(1):26-38.

Nussbaum M. 2001. Upheavals of Thought: The Intelligence of Emotions. Cambridge: Cambridge University Press.

Simons M. 2006. Education through research at European Universities: Notes on the orientation of academic research. Journal of Philosophy of Education, 40(1):31-50.

Singh M. 2001. Re-inserting the 'public good' into higher education transformation. Kagisano Higher Education Discussion Series 1. Pretoria: Kagiso.

Teferra D \& Altbach P. 2003. Trends and perspectives in African higher education. In: D Teferra \& P Altbach (eds). African Higher Education: An International Reference Handbook. Bloomington \& Indianapolis: Indiana University Press.

Waghid Y. 2007. Education, responsibility and democratic justice: Cultivating friendship to alleviate some of the injustices on the African continent. Educational Philosophy and Theory, 39(2): 182-196.

Waghid Y. 2008. The public role of the university reconsidered. Perspectives in Education, 26(1):19-24.

Waghid Y. 2009. Challenges for higher education in Africa, ubuntu and democratic justice. In: C Caloun \& D Rhoten (eds). Changes in Higher Education. New York: Social Sciences Research Council. Forthcoming. 